\title{
Value of Serum- Ascites Albumin Gradient in Prediction of Presence and Severity of Gastric Varices in Cirrhotic Ascitic Patients
}

\author{
Taghrid M. Abdalla ${ }^{1}$, Sameh M. Abdel Monem ${ }^{1}$, Essam A Wahab ${ }^{2}$, \\ Hosam M. Dawod ${ }^{1}$ and Mokhtar A. Ibrahem ${ }^{3}$ \\ Departments of: Tropical Medicine ${ }^{1}$, Internal Medicine ${ }^{2}$ and Clinical Pathology ${ }^{3}$ \\ Faculty of Medicine, Zagazig University, Egypt.
}

Corresponding Author Taghrid M. Abdalla

Mobile:002010146162 11

E mail:tagkomy@gmail. com

Key words: Portal hypertension, liver cirrhosis, gastric varices, serum- ascitic albumin gradient
Background and aim of the work: Gastric varices $(\mathrm{GV})$ are an ominous complication of portal hypertension (PH). The prediction of $\mathrm{GV}$ is a mandatory request to avoid their risky bleeding. This work aimed at evaluating the value of Serum- Ascitic Albumin Gradient (SAAG) in prediction of the presence and severity of $\mathrm{GV}$ in cirrhotic ascitic patients.

Patients and methods: A descriptive cross-sectional study was conducted on 75 cirrhotic ascitic patients. All participants were subjected to full history taking, thorough clinical examination and laboratory investigations including liver function tests, complete blood count, kidney function tests and hepatitis markers including anti hepatitis $\mathrm{C}$ virus antibody (HCV-Abs) and hepatitis B surface antigen (HBs-Ag). Abdominal ultrasonography and abdominal diagnostic paracentesis with calculation of
SAAG were also done. Patients were also subjected to upper gastrointestinal (GI) endoscopy and they were divided into two main groups according to the presence or absence of GV. Patients with GV were further classified into three groups depending on the form and size of GV.

Results: SAAG - at a cut off value $\geq 2.4$ $\mathrm{gm} / \mathrm{dl}$ - predicted the presence of gastric varices with $93.28 \%$ specificity, 59.92 $\%$ positive predicting value, $66.67 \%$ sensitivity and $96.5 \%$ negative predicting value. SAAG value also showed a highly significant increase with the progression of grades of $\mathrm{GV}$.

Conclusion: Serum- ascites albumin gradient (SAAG) could be considered as an efficient non-invasive predictor for the presence of $\mathrm{GV}$ and could reflect the severity of G.V in cirrhotic ascitic patients.

\section{INTRODUCTION}

Liver cirrhosis with the eventual portal hypertension $(\mathrm{PH})$ are the most critical result of chronic liver diseases. Portal hypertension has many complications including oesophageal varices $(\mathrm{OV})$, gastric varices $(\mathrm{GV})$ and portal hypertensive gastropathy (PHG) [1]. GV represent an important finding in about $20 \%$ of cirrhotic patients with portal hypertension [2]. Unlike OV, the afferent veins of GV are mainly from the short gastric, left gastric and polar renal veins. Bleeding from $\mathrm{GV}$ is less frequent but more critical than OV. It is more related to the size and wall tension of the varix than to the degree of PH [3]. Risk factors for bleeding GV are mainly the degree of severity of liver disease, size, location and the presence of red spots on the varix [4-6]. Few published literatures are available about the management of GV. Moreover, most data depend on expert opinion and are not evidence- based [3].

GV were classified according to their anatomical position into four types.

1- Gastro- oesophageal varices- 1 (GOV-1); which is the most common type of GV (about 75\%) extending from the cardia to the lesser curvature and mostly (about 93\%) associated with large OV. 
2- Gastro- oesophageal varices- 2 (GOV-2); which extend from the cardias to the fundus of the stomach. They represent about $21 \%$ of all cases of GV and are 50\% associated with large OV.

3- Isolated gastric varices- 1 (IGV-1); which are located on the fundus of the stomach and not accompanied by OV. They represent only about $1.6 \%$ of GV patients.

4- Isolated gastric varices- 2 (IGV-2); which are not accompanied by OV. They are located in the stomach but not the fundus. They represent about $2.4 \%$ of $\mathrm{GV}$ patients and mostly after endoscopic obliteration of OV or GV [7].

Another classification according to Hashizume et al [8], GV group is further classified according to

- Form, into three types that met the classification of Triantafyllou et al [9].
a. F1: Tortuous $(<5 \mathrm{~mm})$.
b. F2: Nodular $(5-10 \mathrm{~mm})$.
c. F3: Tumorous $(>10 \mathrm{~mm})$.

- Location, into five types that depend on hemodynamic factors.
a. Anterior (La).
b. Posterior (Lp).
c. Lesser curvature (Ll).
d. Greater curvature (Lg) of the cardia and.
e. Fundic area (Lf).

- Color, into two types.
a- White.
b- Red.

Serum-Ascites Albumin Gradient (SAAG) is calculated by subtracting the ascetic fluid albumin from the serum albumin in simultaneously collected samples [10]. It is a minimally invasive precise diagnostic and predictive tool in portal hypertensive patients [11]. SAAG was found to be correlated with OV and was recommended as a significant predictor of their presence and progression $[12,13]$. However, limited data are available about the relation between SAAG and GV. Moreover, the few published literatures about the management of $\mathrm{GV}$ is a situation stressing the need to evaluate a non- invasive method - such as SAAG - for this purpose.

This work aims at evaluating the value of SerumAscitic Albumin Gradient (SAAG) in prediction of the presence and severity of GV in cirrhotic ascitic patients.

\section{PATIENTS AND METHODS}

A descriptive cross-sectional study was conducted in Tropical medicine Department and Internal Medicine Department, Zagazig University Hospitals, during the period from January 2019 to June 2019. A number of 75 HCV cirrhotic patients with ascites were recruited to the study during this period. They were 60 males and 15 females. Their age ranged from 40 to 75 years.

\section{Inclusion criteria:}

Cirrhotic ascitic patients without any history of hematemesis melena and /or bleeding rectum were included in the study.

\section{Exclusion criteria:}

Hemodynamic instability including history of hematemesis, melena and / or bleeding rectum. Chronic renal failure, hepatopulmonary syndrome, portal or splenic vein thrombosis, uncontrolled hepatic encephalopathy, spontaneous bacterial peritonitis, hepatorenal syndrome, history of active and/ or past alcohol use, previous surgery for portal hypertension, splenectomy, previous endoscopic treatment (band ligation, sclerotherapy) or transjugular intrahepatic portosystemic shunt (TIPS) and pregnant ladies were excluded from the study.

Methods:

\section{All patients were subjected to the following:}

1. Full history taking

2. Detailed clinical examination.

3. Laboratory investigations:

a- Liver function tests by using (Dimension Rx1 Autoanalyzer from Siemens).

b- Complete blood count by using (system $\mathrm{xkx} 21$ from Roche diagnosis).

c- Kidney function tests: as serum creatinine, blood urea nitrogen by using (Dimension Rx1 Autoanalyzer from Siemens).

d- Hepatitis markers: HCV-Ab (anti hepatitis c virus antibody) by using (VITROS AntiHCV Reagent Pack on the VITROS 3600 Immunodiagnostic System hepatitis B surface antigen (HBs-Ag) by using the VITROS Anti-HBc Reagent Pack on the VITROS 3600 Immunodiagnostic System.

e- Prothrombin time (PT) and International Normalized Ratio (INR).

f- C- reactive protein.

4. Pelvi- abdominal ultrasonography was performed by Esoate MYLab20Plus to 
assess criteria indicating liver cirrhosis, portal hypertension and the presence or absence of ascites [14].

5. Child- Turcotte- Pugh (CTP) score was calculated for all patients who were categorized into Child A, B and C [15].

6. Endoscopic evaluation: all patients were subjected to upper gastrointestinal (GI) endoscopy using GIF 230 Olympus or pentax EPM 3500 video esophago-gastroduodenoscope. Experienced gastroenterologists blinded to the patients clinical and laboratory data detected all endoscopic findings. According to upper GI endoscopy, patients were divided into two groups:

- Group I (G I): comprised 15 cirrhotic ascitic patients without GV.

- Group II (G II): comprised 60 cirrhotic ascitic patients with GV who were classified according to Hashizume and Triantafyllou [8,9], into three sub- groups based on the size and form of GV.

F1: Tortuous: < 5mm (32 patients).

F2: Nodular: 5- $10 \mathrm{~mm}$ (22 patients).

F3: Tumorous: > 10mm (6 patients).

7. Abdominal diagnostic paracentesis and samples collection was done for all patients under complete aseptic conditions [16].

\section{Statistical Analysis}

All data were collected, computerized and statistically analyzed using SPSS program (Statistical Package for Social Science) version 24. Data of normal distribution were tested using the Shapiro Walk test. Qualitative data were represented as frequencies and relative percentages. Chi square test $\left(\chi^{2}\right)$ and Fisher exact was used to calculate difference between qualitative variables as indicated. Quantitative data were expressed as mean $\pm \mathrm{SD}$. Independent $\mathrm{T}$ test was used to calculate difference between quantitative variables in two groups. One-way ANOVA F-test was used to calculate difference between quantitative variables in more than two groups. All statistical comparisons were conducted with significance level of P-value $\leq 0.05$ indicates significant, $\mathrm{p}<0.001$ indicates highly significant difference while, $\mathrm{P}>0.05$ indicates Non-significant difference.

\section{RESULTS}

Out of 75 cirrhotic ascitic patients, males were 60 and females were 15. Their ages ranged from
(40-75) years, where 70 patients were from rural areas and 5 from urban areas (table-1).

It was found that 55 patients $(73.4 \%)$ had massive ascites, 48 patients (64\%) had Jaundice and 64 patients $(85.3 \%)$ had lower limb oedema. Regarding Child- Pugh score 29 patients were Child B (38.6\%) and 64 patients were Child C (61.4\%) (table- 2).

There is no significant difference between the studied groups as regard sex and residence, while there is significant difference as regard age (table- 3).

There is a highly significant difference between the studied groups as regard child score. There is a significant difference between the studied groups as regard jaundice and Child- Pugh category, while there is no significant difference as regard the presence of ascites and lower limb edema (table- 4).

There is statistically significant difference between the studied groups regarding spleen diameter, the presence of splenomegaly and shrunken liver. While there is no statistically significant difference among the studied groups regarding portal vein (PV) diameter (table- 5).

There is a highly significant difference regarding SAAG values among studied groups. SAAG value increased significantly with the progression of the grade of GV from the group without GV to F3 group (table- 6).

There was significant to highly significant positive correlation between SAAG and (total bilirubin, direct bilirubin, serum albumin, Creactive protein, INR and age) among patients with GV; while There was significant positive correlation between SAAG and (total bilirubin, direct bilirubin and Child score) among patients without GV. In addition, there was significant to highly significant negative correlation between SAAG and (platelets, ALT, AST, haemoglobin level and albumin in ascitic fluid) among patients with GV; while there was highly significant negative correlation between SAAG and albumin in ascites among patients without GV (table- 7).

The area under the curve (AUC) is (0.884). ROC curve showed that SAAG at a cut off value $\geq$ $2.4 \mathrm{gm} / \mathrm{dl}$ could predict the presence of gastric varices with $93.28 \%$ specificity, $59.92 \%$ positive predicting value, $66.67 \%$ sensitivity and $96.5 \%$ negative predicting value (table- 8 ).

Abdalla et al., Afro-Egypt J Infect Endem Dis 2020; 10(1):16-23

https://aeji.journals.ekb.eg/

http://mis.zu.edu.eg/ajied/home.aspx 
Table 1: Demographic data of the studied population $(\mathrm{N}=75)$.

\begin{tabular}{|l|c|c|c|}
\hline \multicolumn{2}{|c|}{ Variable } & N. & \% \\
\hline \multirow{2}{*}{ Age, years } & $\begin{array}{c}\text { Mean } \pm \text { SD } \\
\text { Median (Range) }\end{array}$ & \multicolumn{2}{|c|}{$61.2 \pm 6.5$} \\
$61(40-75)$ \\
\hline \multirow{2}{*}{ Sex } & Female & 15 & $20 \%$ \\
\hline \multirow{2}{*}{ Residence } & Male & 60 & $80 \%$ \\
\cline { 2 - 4 } & Rural & 70 & $93.3 \%$ \\
\cline { 2 - 4 } & Urban & 5 & $6.6 \%$ \\
\hline
\end{tabular}

Table 2: Clinical findings of the studied populations $(\mathrm{N}=75)$.

\begin{tabular}{|c|c|c|c|c|}
\hline \multicolumn{3}{|c|}{ Variable } & $\mathbf{N}$. & $\%$ \\
\hline \multirow{6}{*}{ Clinical Features } & \multirow{2}{*}{ Ascites } & Moderate & 20 & $26.6 \%$ \\
\hline & & Massive & 55 & $73.4 \%$ \\
\hline & \multirow{2}{*}{ Jaundice } & Absent & 27 & $36 \%$ \\
\hline & & Present & 48 & $64 \%$ \\
\hline & \multirow{2}{*}{$\begin{array}{c}\text { Lower limb } \\
\text { odema }\end{array}$} & Absent & 11 & $14.7 \%$ \\
\hline & & Present & 64 & $85.3 \%$ \\
\hline \multirow{4}{*}{ Child- Pugh } & \multirow{2}{*}{ Category } & B & 29 & $38.6 \%$ \\
\hline & & $\mathrm{C}$ & 46 & $61.4 \%$ \\
\hline & \multirow{2}{*}{ Score } & Mean \pm SD & \multicolumn{2}{|c|}{$10.1 \pm 1.8$} \\
\hline & & Median (Range) & \multicolumn{2}{|c|}{$10(7-13)$} \\
\hline
\end{tabular}

Table 3: Demographic Findings among the studied groups.

\begin{tabular}{|c|c|c|c|c|c|c|c|c|}
\hline & \multirow{2}{*}{$\begin{array}{c}\text { Group I } \\
\text { (No GV) } \\
\mathbf{N}=15\end{array}$} & \multicolumn{3}{|c|}{ Group II (GV) } & \multirow[b]{2}{*}{$\begin{array}{l}\text { Total } \\
N=75\end{array}$} & \multirow[b]{2}{*}{ Test } & \multirow[b]{2}{*}{$\mathbf{P}$} \\
\hline & & & $\begin{array}{c}\mathrm{F} 1 \\
\mathrm{~N}=32\end{array}$ & $\begin{array}{c}\mathrm{F} 2 \\
\mathrm{~N}=22\end{array}$ & $\begin{array}{c}F 3 \\
N=6\end{array}$ & & & \\
\hline \multicolumn{2}{|l|}{ Age, years } & $59.8 \pm 6.5$ & $58.1 \pm 8.4$ & $62.1 \pm 7.9$ & $58.9 \pm 4.3$ & $60 \pm 7.8$ & 2.7 & $0.033^{*}$ \\
\hline \multirow{2}{*}{ Sex } & Female & $2(13.3 \%)$ & $9(28.1 \%)$ & $4(18.2 \%)$ & $0(0.0 \%)$ & $15(20 \%)$ & \multirow{2}{*}{6.4} & \multirow{2}{*}{0.17} \\
\hline & Male & $13(86.7 \%)$ & $23(71.9 \%)$ & $18(81.8 \%)$ & $6(100.0 \%)$ & $60(80 \%)$ & & \\
\hline \multirow{2}{*}{ Residence } & Rural & $14(93.3 \%)$ & $30(93.8 \%)$ & $21(95.5 \%)$ & $5(83.3 \%)$ & $70(93.3 \%)$ & \multirow[b]{2}{*}{4.6} & \multirow{2}{*}{0.328} \\
\hline & Urban & $1(6.7 \%)$ & $2(6.2 \%)$ & $1(4.5 \%)$ & $1(16.7 \%)$ & $5(6.7 \%)$ & & \\
\hline
\end{tabular}

All variables were compared using Chi-square $\mathrm{X}^{2}$ test except (age) One-way ANOVA test All variables were expressed using their No. (\%) except (age) by Mean \pm SD.

* significant.

$\mathrm{GV}$ : gastric varices.

Table 4: Clinical Findings \& Child score among the studied groups.

\begin{tabular}{|c|c|c|c|c|c|c|c|c|}
\hline & \multirow{2}{*}{$\begin{array}{c}\text { Group I } \\
\text { (No GV) } \\
\text { N=15 }\end{array}$} & \multicolumn{3}{|c|}{ Group II (GV) } & \multirow[b]{2}{*}{$\begin{array}{l}\text { Total } \\
\text { N=75 }\end{array}$} & \multirow[b]{2}{*}{ Test } & \multirow[b]{2}{*}{$\mathbf{P}$} \\
\hline & & & $\begin{array}{c}\mathbf{F} 1 \\
\mathrm{~N}=32\end{array}$ & $\begin{array}{c}\mathrm{F} 2 \\
\mathrm{~N}=22\end{array}$ & $\begin{array}{c}F 3 \\
N=6\end{array}$ & & & \\
\hline \multirow{2}{*}{ Ascites } & Mod & $6(40 \%)$ & $9(28.1 \%)$ & $3(13.6 \%)$ & $2(33.3 \%)$ & $20(26.6 \%)$ & \multirow{2}{*}{5.5} & \multirow{2}{*}{0.249} \\
\hline & Mas & $9(60 \%)$ & $23(71.8 \%)$ & $19(86.4 \%)$ & $4(66.7 \%)$ & $55(73.3 \%)$ & & \\
\hline \multirow{2}{*}{ Jaundice } & Absent & $7(46.7 \%)$ & $15(46.8 \%)$ & $5(22.7 \%)$ & $0(0.0 \%)$ & 27 & \multirow[b]{2}{*}{16.1} & \multirow{2}{*}{$0.004 *$} \\
\hline & Present & $8(53.3 \%)$ & $17(53.1 \%)$ & $17(77.3 \%)$ & $6(100.0 \%)$ & 48 & & \\
\hline \multirow{2}{*}{$\begin{array}{l}\text { LL } \\
\text { Edema }\end{array}$} & Absent & $3(20 \%)$ & $6(18.7 \%)$ & $3(13.6 \%)$ & $0(0.0 \%)$ & $11(14.7 \%)$ & \multirow{2}{*}{5.3} & \multirow{2}{*}{0.266} \\
\hline & Present & $12(70 \%)$ & $26(81.3 \%)$ & $19(86.4 \%)$ & $6(100.0 \%)$ & $64(85.3 \%)$ & & \\
\hline \multirow{2}{*}{\begin{tabular}{|l} 
Child \\
category
\end{tabular}} & B & $9(60 \%)$ & $13(40.6 \%)$ & $5(22.7 \%)$ & $2(33.3 \%)$ & $29(38.7 \%)$ & \multirow{2}{*}{13.8} & \multirow{2}{*}{$0.007 *$} \\
\hline & $\mathrm{C}$ & $6(40 \%)$ & $19(59.4 \%)$ & $17(77.3 \%)$ & $4(66.7 \%)$ & 46( & & \\
\hline \multicolumn{2}{|c|}{ Child Score } & $8.9 \pm 1.2$ & $9.8 \pm 1.6$ & $10.9 \pm 1.5$ & $10.7 \pm 2.6$ & $10.1 \pm 1.8$ & 6.3 & $<0.001 * *$ \\
\hline
\end{tabular}

All variables were compared using Chi-square $\mathrm{X}^{2}$ test except (Child score) One-way ANOVA test

All variables were expressed using their No. (\%) except (Child score) by Mean \pm SD.

* significant. ** highly significant. GV: gastric varices

Abdalla et al., Afro-Egypt J Infect Endem Dis 2020; 10(1):16-23

https://aeji.journals.ekb.eg/

http://mis.zu.edu.eg/ajied/home.aspx 
Table 5: Comparison of ultrasonographic data among the studied groups.

\begin{tabular}{|c|c|c|c|c|c|c|c|c|c|}
\hline & \multirow{2}{*}{$\begin{array}{c}\text { Group I } \\
\text { (No GV) } \\
\mathbf{N}=15 \\
\end{array}$} & \multicolumn{3}{|c|}{ Group II (GV) } & \multirow[b]{2}{*}{$\begin{array}{l}\text { Total } \\
N=75\end{array}$} & \multirow[b]{2}{*}{ Test } & \multirow[b]{2}{*}{$\mathbf{P}$} \\
\hline & & & & $\begin{array}{c}\mathbf{F} \mathbf{1} \\
\mathrm{N}=32\end{array}$ & $\begin{array}{c}\mathbf{F} 2 \\
\mathrm{~N}=22\end{array}$ & $\begin{array}{c}\begin{array}{c}F 3 \\
N=6\end{array}\end{array}$ & & & \\
\hline \multicolumn{3}{|c|}{ Spleen Diameter, mm } & $17 \pm 1.1$ & $16.6 \pm 1.2$ & $16.5 \pm 1.1$ & $17.3 \pm 0.8$ & $16.9 \pm 1.2$ & 2.7 & $0.036^{*}$ \\
\hline \multirow{2}{*}{\multicolumn{2}{|c|}{ Splenomegaly }} & Absent & $2(13.3 \%)$ & $2(6.25 \%)$ & $1(5.3 \%)$ & $1(16.6 \%)$ & $6(8 \%)$ & \multirow{2}{*}{7.9} & \multirow{2}{*}{$0.048 *$} \\
\hline & & Present & $13(86.7 \%)$ & $30(93.75 \%)$ & $21(94.7 \%)$ & $5(83.3 \%)$ & $69(92 \%)$ & & \\
\hline \multicolumn{3}{|c|}{ Portal vein diameter, $\mathbf{m m}$} & $15.3 \pm 0.8$ & $15.4 \pm 0.7$ & $15.5 \pm 0.8$ & $15.6 \pm 0.7$ & $157 \pm 0.8$ & 2.3 & 0.06 \\
\hline \multirow{2}{*}{ Liver } & & erage & $5(33.3 \%)$ & $9(28.1 \%)$ & $2(9.1 \%)$ & $1(16.6 \%)$ & $17(22.7 \%)$ & \multirow{2}{*}{11.6} & \multirow{2}{*}{$0.02 *$} \\
\hline & \multicolumn{2}{|c|}{ Shrunken } & $10(66.7 \%)$ & $23(71.9 \%)$ & $20(90.9 \%)$ & $5(83.3 \%)$ & $58(77.3 \%)$ & & \\
\hline
\end{tabular}

All variables were compared using Chi-square $\mathrm{X}^{2}$ test except (spleen and portal vein diameters) One-way ANOVA test. All variables were expressed using their $\mathrm{N}(\%)$ except (spleen and portal vein diameters) by Mean \pm SD.

* significant. GV: gastric varices

Table 6: Comparison of SAAG values among the studied groups.

\begin{tabular}{|c|c|c|c|c|c|c|}
\hline & \multirow{2}{*}{$\begin{array}{c}\text { Group I } \\
\text { (No GV) } \\
\mathrm{N}=15\end{array}$} & \multicolumn{3}{|c|}{ Group II (GV) } & \multirow[b]{2}{*}{ F test } & \multirow[b]{2}{*}{ Sig. } \\
\hline & & $\begin{array}{c}\text { F 1 } \\
\mathrm{N}=32\end{array}$ & $\begin{array}{c}\text { F } 2 \\
\mathrm{~N}=22\end{array}$ & 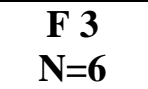 & & \\
\hline SAAG & $1.9 \pm 0.1$ & $2.8 \pm 0.4$ & $3.9 \pm 0.2$ & $4.4 \pm 0.2$ & 254.9 & $<0.001 * *$ \\
\hline
\end{tabular}

All variables were compared using One-way ANOVA $(\mathrm{F})$ test $\&$ expressed by Mean \pm SD.

**highly significant. GV: gastric varices. SAAG: serum- ascitic albumin gradient.

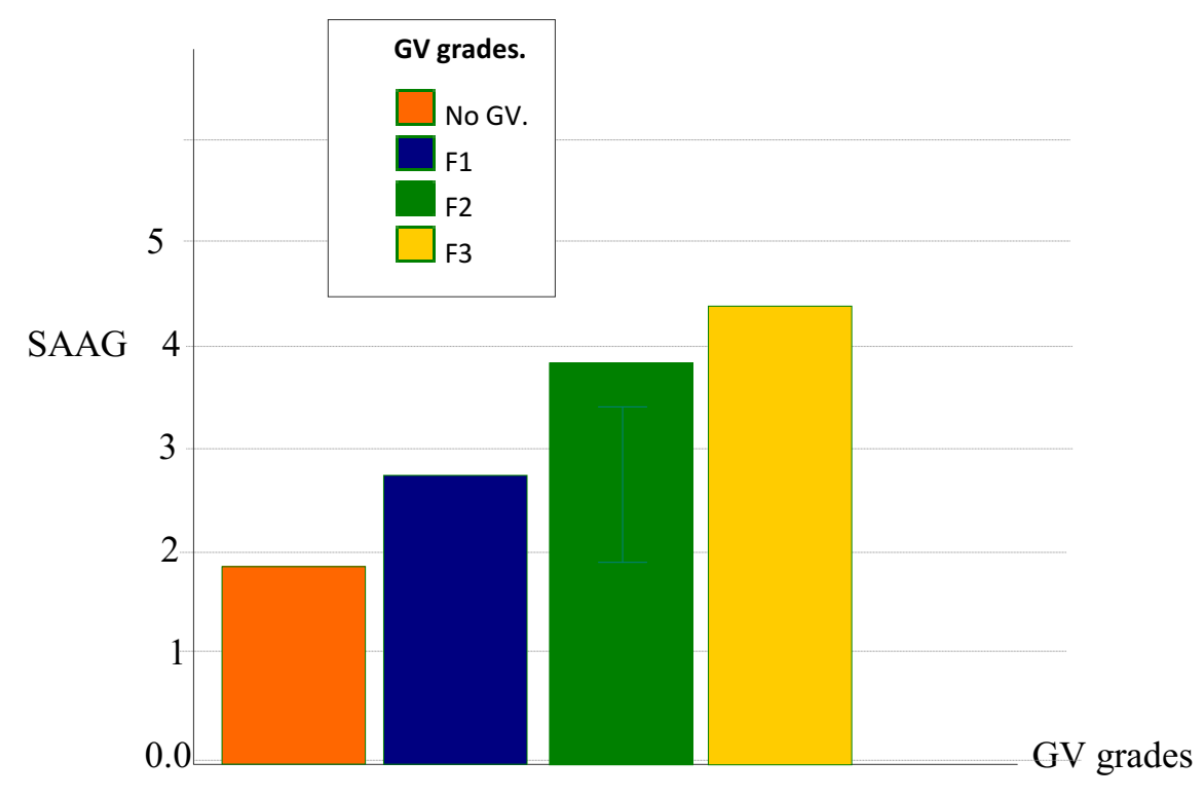

Figure 1: The blot diagram showing there is highly significant correlation between serum- ascitic albumin gradient (SAAG) and GV grades in studied groups. 
Table 7: Correlations between calculated SAAG value and other parameters in study groups Group I and Group II.

\begin{tabular}{|l|c|c|c|c|}
\hline \multirow{2}{*}{} & \multicolumn{2}{|c|}{ Group I (No GV) } & \multicolumn{2}{c|}{ Group II (GV) } \\
\cline { 2 - 5 } & $\mathbf{R}$ & $\mathbf{P}$ & $\mathbf{R}$ & $\mathbf{P}$ \\
\hline Age(years) & 0.461 & 0.009 & 0.249 & $0.012^{*}$ \\
\hline Portal vein diameter(mm) & 0.331 & 0.059 & 0.189 & 0.07 \\
\hline Spleen Diameter(mm) & 0.142 & 0.423 & 0.173 & 0.079 \\
\hline WBCs $\left(\times 10^{3} / \mathrm{Ul}\right)$ & 0.057 & 0.749 & 0.034 & 0.75 \\
\hline Hemoglobin $(\mathrm{gm} / \mathrm{dl})$ & -0.12 & 0.520 & -0.311 & $0.019^{*}$ \\
\hline Platelets $\left(\times 10^{3} / \mathrm{Ul}\right)$ & 0.167 & 0.354 & -0.457 & $<0.001^{* *}$ \\
\hline Total bilirubin(mg/dl) & 0.529 & 0.028 & 0.45 & $<0.001^{* *}$ \\
\hline Direct bilirubin(mg/dl) & 0.534 & 0.002 & 0.406 & $<0.001^{* *}$ \\
\hline Serum albumin(g/dl) & 0.067 & 0.711 & 0.545 & $<0.001^{* *}$ \\
\hline ALT (unit/liter) & -0.20 & 0.248 & -0.397 & $<0.001^{* *}$ \\
\hline AST (unit/liter) & -0.112 & 0.551 & -0.417 & $<0.001^{* *}$ \\
\hline INR & -0.014 & 0.929 & 0.28 & $0.004^{*}$ \\
\hline Prothrombin time (second) & 0.261 & 0.157 & 0.171 & 0.095 \\
\hline C- reactive protein $(\mathrm{mg} / \mathrm{dl})$ & 0.340 & 0.059 & 0.51 & $<0.001^{* *}$ \\
\hline Child Score & 0.463 & 0.008 & 0.199 & 0.05 \\
\hline Albumin in ascitic fluid & -0.724 & $<0.001$ & -0.575 & $<0.001^{* *}$ \\
\hline
\end{tabular}

$\mathrm{P} \leq 0.05=*$ significant $\mathrm{P}<0.001=* *$ highly significant and $\mathrm{P}>0.05=$ Non-significant.

$\mathrm{r}=$ Correlation Coefficient $\quad$ SAAG: serum- ascitic albumin gradient.

Table 8: Cut of value of SAAG in prediction of the presence of GV.

\begin{tabular}{|c|c|c|c|c|c|c|c|}
\hline $\begin{array}{c}\text { Predictor } \\
\text { for }\end{array}$ & $\begin{array}{c}\text { Cut- } \\
\text { off }\end{array}$ & $\begin{array}{c}\text { Sensitivity } \\
(\mathbf{9 5 \%} \text { CI })\end{array}$ & $\begin{array}{c}\text { Specificity } \\
(\mathbf{9 5 \%} \text { CI })\end{array}$ & $\begin{array}{c}\text { PPV } \\
(\mathbf{9 5 \%} \text { CI })\end{array}$ & $\begin{array}{c}\text { NPV } \\
(\mathbf{9 5 \%} \text { CI })\end{array}$ & $\begin{array}{c}\text { AUC } \\
(\mathbf{9 5 \%} \text { CI) }\end{array}$ & P \\
\hline GV & $>2.4$ & $\begin{array}{c}66.67 \\
(34.9-90.1)\end{array}$ & $\begin{array}{c}93.28 \\
(87.2-97.1)\end{array}$ & $\begin{array}{c}59.92 \\
(31.4-68.6)\end{array}$ & $\begin{array}{c}96.5 \\
(92.6-98.4)\end{array}$ & $\begin{array}{c}0.884 \\
(0.817-0.933)\end{array}$ & $<0.001$ \\
\hline
\end{tabular}

The 95\%CI: 95\% confidence interval, Positive predictive value (PPV) and negative predictive value (NPV), Area under the ROC curve (AUC). SAAG: serum- ascitic albumin gradient. GV gastric varices.

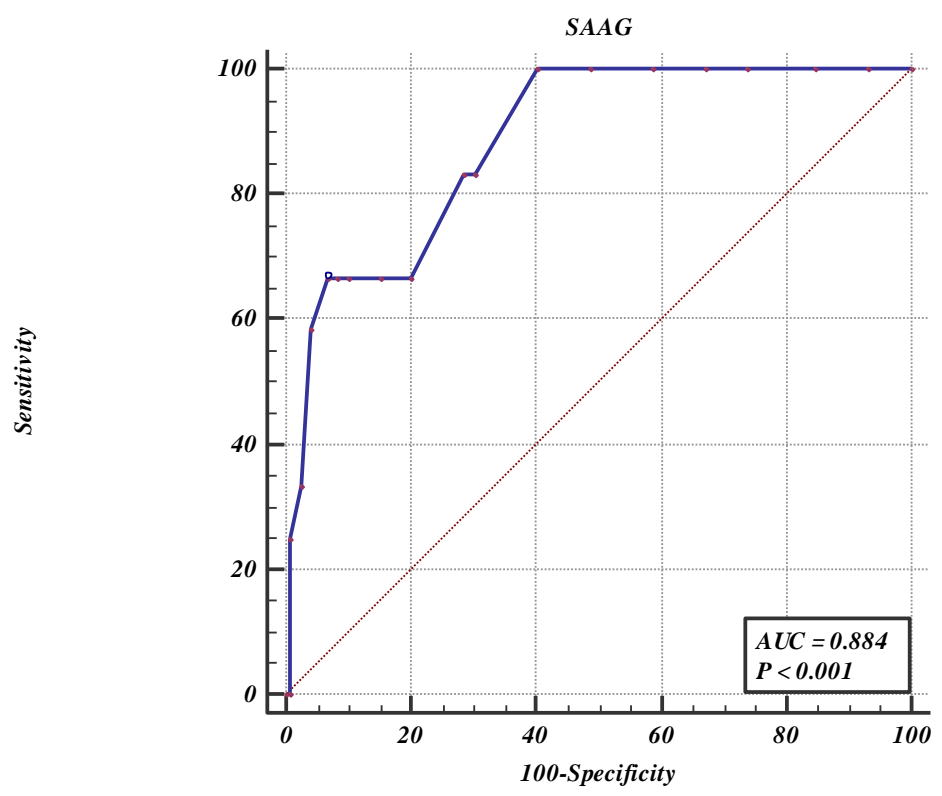

SAAG: serum- ascitic albumin gradient.

Figure 2: Cut of value of SAAG in prediction of the presence of GV.

Abdalla et al., Afro-Egypt J Infect Endem Dis 2020; 10(1):16-23

https://aeji.journals.ekb.eg/

http://mis.zu.edu.eg/ajied/home.aspx 


\section{DISCUSSION}

Gastric varices (GV) are the second most common upper gastrointestinal (UGI) bleeding in portal hypertensive patients after oesophageal varices $(\mathrm{OV})$. Although $\mathrm{GV}$ bleeding is rare yet it is horrible with higher morbidity, mortality and transfusion requirements than OV [17]. Prevention and management of GV first bleeding and rebleeding is lacking the evidence-based recommendation a condition stressing the need to develop and evaluate a non- invasive method for prediction of the presence and severity of GV $[3,18]$. Serum- Ascites Albumin Gradient (SAAG) proved very effective in prediction of OV [12,19], a situation encouraging the researchers to assess its value in prediction of GV.

This work aims at evaluating the value of SerumAscites Albumin Gradient (SAAG) in prediction of the presence and severity of GV in cirrhotic ascitic patients.

This study shows that there is a highly significant difference between the studied groups as regard Child score and a significant difference as regard Child- Pugh category and jaundice. This can be explained because the more severe chronic liver disease the more severe portal hypertension and consequently the GV. This result agrees with those of D'Amico et al., and Kovalak et al., who declared that the prevalence of GV increases with the severity of liver disease represented by Child- Pugh score and grade [20,21]. On the other hand, this result disagrees with that of Ozdil et al., who found no correlation between the size of GV and Child- Pugh grade [23]. This can be explained by the fact that majority of patients in all grades of $\mathrm{GV}$ in their study were belonging to Child class A.

This study shows that there is statistically significant difference between the studied groups as regard splenic size. This result agrees with that of Min et al., who found an independent association of splenic size with the presence of GV [22]. On the other hand, this result disagrees with that of Ozdil et al., who found no statistically significant correlation between the size of varices and splenic diameter in patients with gastric varices [23]. This can be explained by the different criteria of included patients of the two studies.

This study showed that there is a significant difference between the studied groups as regard age. This correlation can be explained by the more time availability for deterioration of the cirrhosis and GV. On the other hand, this result disagree with that of Min et al., who found a non- significant relation [22], a situation that can be explained by the different demographic variables of the studied groups.

This study showed that there was significant positive correlation between SAAG with age, total bilirubin, direct bilirubin, and INR among patient with GV. In addition, there was a highly significant negative correlation between SAAG and (platelets, ALT, AST and Albumin in ascitic fluid) among patients with GV. All these variables could be attributed to the time availability needed for the chronic liver disease to allow such complications to become evident.

This study shows that SAAG value is significantly correlated with the presence of GV. SAAG is also associated with the progression of the grade of $\mathrm{GV}$. At a cut-off value $\geq 2.4 \mathrm{gm} / \mathrm{dl}$ SAAG could predict the presence of GV with 93.28\% specificity, $59.92 \%$ positive predicting value, $66.67 \%$ sensitivity and $96.5 \%$ negative predicting values. To our knowledge there is no previous studies done to evaluate the relation between SAAG and the presence of GV. Despite the fundamental role of upper GI endoscopy in diagnosis of GV, SAAG could be suggested as a useful non-invasive method for prediction of the presence of $\mathrm{GV}$ and could also reflect the progression and severity of their grades. However, further detailed studies are recommended to fully investigate and evaluate this point.

\section{CONCLUSION}

Serum- ascites albumin gradient (SAAG) could be considered as an efficient non-invasive predictor for the presence of $\mathrm{GV}$ and could reflect the severity of G.V in cirrhotic ascitic patients.

Ethical approval: all procedures were approved by Zagazig University Institutional Review Board (IRB), the ethical committee of Zagazig University Hospitals.

Funding: None.

Conflict of interest: None. 


\section{REFERENCES}

1. de Franchis R. Evolving consensus in portal hypertension. Report of the Baveno IV consensus workshop on methodology of diagnosis and therapy in portal hypertension. J Hepatol 2005; 43: 167-176.

2. Sarin SK, Lahoti D, Saxena SP, Murthy NS and Makwana UK. Prevalence, classification and natural history of gastric varices: a long-term follow-up study in 568 portal hypertension patients. Hepatology. 1992; 16: 1343-1349.

3. Vine LJ, Subhani M and Acevedo JG. Update on management of gastric varices .World J Hepatol. 2019; 11(3): 250-260.

4. Kim T, Shijo H, Kokawa H, Tokumitsu H, Kubara K, Ota K, et al. Risk factors for hemorrhage from gastric fundal varices. Hepatology. 1997; 25: 307-312.

5. Komori K, Kubokawa M, Ihara E, Akahoshi K, Nakamura K, Motomura K, et al. Prognostic factors associated with mortality in patients with gastric fundal variceal bleeding. World $J$ Gastroenterol. 2017; 23: 496-504.

6. Triantafyllou $M$ and Stanley AJ. Update on gastric varices. World J Gastrointest Endosc. 2014; 6: 168-175.

7. Sarin SK, Jain AK, Lamba GS, Gupta R and Chowdhary A. Isolated gastric varices: prevalence, clinical relevance and natural history. Dig Surg. 2003; 20: 42-47.

8. Hashizume M, Kitano S, Yamaga H, Koyanagi N and Sugimachi K. Endoscopic classification of gastric varices. Gastrointest Endosc. 1990; 36: 276-80.

9. Triantafyllou $\mathrm{M}$ and Stanley AJ. Update on gastric varices. World J Gastrointest Endosc 2014; 6:168-75.

10. Sandhu BS and Sanyal AJ. Management of ascites in cirrhosis. Clin Liver Dis 2005; 9(4): 715-732.

11. Shahed FH, Al-Mahtab M and Salimur Rahman. The Evaluation of Serum Ascites Albumin Gradient and Portal Hypertensive changes in Cirrhotic Patients with Ascites. Euroasian $J$ Hepatogastroenterol. 2016; 6(1): 8-9.

12. Sayyed J, Sharma D, Choudhary K, Meena SR and Pallavi Vij. A Study on Correlation between SAAG and Platelet Count: Spleen Size Ratio for the Prediction of Esophageal Varices among
Chronic Liver Disease Patients. Indian Journal of Basic and Applied Medical Research. 2018; 7(3):502 - 508.

13. Ananissoh LML, Bagny A, Bouglouga O, Ganbobo IMS, Yakoubou RE, Kogoe L, et al. Interest of Serum-Ascites Albumin Concentration Gradient in the Diagnosis of Portal Hypertension in Cirrhotic Patients. Open Journal of Gastroenterology, 2019; 9(1): Article ID:89986,9 pages.

14. Di Lelio A, Cestari C, Lomazzi A and Beretta L. Cirrhosis: diagnosis with sonographic study of the liver surface. Radiology. 1989;172(2):389392.

15. Child CG and Turcotte JG. The Liver and Portal Hypertension. Philadelphia: Saunders; 1964. Surgery and Portal Hypertension; pp. 50-64.

16. Thomsen TW, Shaffer RW, White B and Setnik GS. Videos in clinical medicine. Paracentesis. $N$ Engl J Med. 2006 Nov 9. 355(19):e21.

17. Sarin S K and Kumar A. Gastric varices: profile, classification, and management. Am J Gastroenterol. 1989;84(10):1244-1249.

18. Al-Osaimi AMS and Caldwell SH. Medical and Endoscopic Management of Gastric Varices. Semin Intervent Radiol. 2011 Sep; 28(3): 273282.

19. Hou Y, Yang Z, Yang Y, Gao F, Liu X, Zhang Q, et al. Original Article Serum-ascites albumin gradient: an independent predictor of esophageal variceal bleeding in cirrhosis patients with ascites. Int J Clin Exp Med 2019;12(7):86458653.

20. D'Amico G, Pagliaro L and Bosch J. The treatment of portal hypertension: a meta-analytic review. Hepatology. 1995;22:332-354.

21. Kovalak M, Lake J, Mattek N, Eisen G, Lieberman D and Zaman A. Endoscopic screening for varices in cirrhotic patients: data from a national endoscopic database. Gastrointest Endosc. 2007;65:82-88.

22. Min YW, Bae SY, Gwak GY, Paik YH, Choi MS, Lee JH, et al. A clinical predictor of varices and portal hypertensive gastropathy in patients with chronic liver disease. Clinical and molecular hepatology 2012; 18(2): 178-184.

23. Ozdil K, Ozturk O, Calık ES, Akbas ES, Kanat E, Calıskan Z, et al. Relationship between size of varices and platelet count/spleen size ratio in cirrhotic patients. North Clin Istanb. 2016; 3(1): 46-52. 